\title{
Correction to: The Singh-Maddala distribution: properties and estimation
}

\author{
Devendra Kumar ${ }^{1}$
}

Published online: 23 February 2021

(C) The Society for Reliability Engineering, Quality and Operations Management (SREQOM), India and The Division of Operation and Maintenance, Lulea University of Technology, Sweden 2021

\section{Correction to: Int J Syst Assur Eng Manag (November 2017) 8(Suppl. 2):S1297-S1311 https://doi.org/10.1007/s13198-017-0600-1}

"The uniqueness of this study comes from the fact that we provide explicit expressions for single and product moments using GOS for SM distribution," on page 3, line 6, paragraph 2 of Sect. 1 should read as:
"Section 3 is in line with the work carried out in Kumar (2015b), which also relates to Khan and Khan (2012) work on single and product moments for Burr distribution.

The original article can be found online at https:// doi.org/10.1007/s13198-017-0600-1.

\footnotetext{
Devendra Kumar

devendrastats@gmail.com

1 Department of Statistics, Central University of Haryana, Mahendergarh, India
} 